Check for updates

Cite this: RSC Adv., 2018, 8, 34947

\title{
One-dimensional chain structures of hexanuclear uranium(IV) clusters bridged by formate ligands $\uparrow$
}

\begin{abstract}
Jie Ling, (DD *a Huangjie Lu, ${ }^{\text {b }}$ Yaxing Wang, ${ }^{\mathrm{b}}$ Kenndra Johnson ${ }^{\mathrm{a}}$ and Shuao Wang (D) ${ }^{\mathrm{b}}$
Three one-dimensional chain structures of uranium(Iv) hexanuclear clusters have been synthesized under hydrothermal/solvothermal conditions. Crystallographic studies disclose that the structures of $\left[\mathrm{U}_{6} \mathrm{O}_{4}(\mathrm{OH})_{4}(\mathrm{HCOO})_{12}\left(\mathrm{H}_{2} \mathrm{O}\right)\right] \cdot 3 \mathrm{H}_{2} \mathrm{O} \quad(1 \mathrm{a}), \quad\left[\mathrm{U}_{6} \mathrm{O}_{4}(\mathrm{OH})_{4}(\mathrm{HCOO})_{12}(\mathrm{HCOOH})\left(\mathrm{H}_{2} \mathrm{O}\right)\right] \cdot 3 \mathrm{H}_{2} \mathrm{O} \quad(1 \mathrm{~b}) \quad$ and $\left(\mathrm{H}_{6} \mathrm{C}_{5} \mathrm{~N}\right)_{2}\left[\mathrm{U}_{6} \mathrm{O}_{4}(\mathrm{OH})_{4}(\mathrm{HCOO})_{14}\left(\mathrm{H}_{5} \mathrm{C}_{5} \mathrm{~N}\right)\right]$ (2) contain a $\mathrm{U}(\mathrm{IV})$ hexanulear core $\left[\mathrm{U}_{6}\left(\mu_{3}-\mathrm{OH}\right)_{4}\left(\mu_{3}-\mathrm{O}\right)_{4}\right]^{12+}$ which is decorated by terminal $\mathrm{HCOO}^{-}$ligands and water $(1 \mathrm{a}, 1 \mathrm{~b}), \mathrm{HCOOH}(1 \mathrm{~b})$ or pyridine molecules (2). These hexanuclear U(IV) clusters are further linked into zig-zag 1-D chain structures via bridging $\mathrm{HCOO}^{-}$ ligands. UV-vis-NIR spectra, together with bond valence calculations, indicate that all $U$ atoms in three compounds exist as U(IV). Magnetic susceptibility data reveal that compound 2 exhibits paramagnetic characteristics.
\end{abstract}

Received 27th July 2018

Accepted 8th October 2018

DOI: $10.1039 / \mathrm{c} 8 \mathrm{ra06330c}$

rsc.li/rsc-advances

Berthet synthesized four hexanuclear $\mathrm{U}(\mathrm{iv})$ clusters, $\left[\mathrm{U}_{6} \mathrm{O}_{8}(-\right.$

\section{Introduction}

Actinide oxo clusters are of high interest because of their implication in nuclear waste disposal and actinide migration in the environment. ${ }^{1-5}$ For tetravalent actinides An(Iv), it is known that they have strong tendencies to hydrolyze in aqueous solution and form a variety of actinide hydroxides $\mathrm{An}(\mathrm{OH})_{n}{ }^{4-n}$, which can further condense and result in the formation of polynuclear clusters, aggregates and even colloids. ${ }^{6-8}$ Such species may be highly mobile in aqueous system and dramatically influence the transport and migration of radionuclides in the environment as has been demonstrated for $\mathrm{Pu}(\mathrm{Iv}) \cdot{ }^{9-11} \mathrm{U}(\mathrm{IV})$, the major component in nuclear fuel, it can form soluble polynuclear clusters rather than insoluble $\mathrm{UO}_{2}$ by bioreduction of hexavalent $\mathrm{U}(\mathrm{vI})$ with bacterias. ${ }^{12,13}$

The first structurally characterized high nuclearity U(IV) cluster, $\mathrm{U}_{6}(\mathrm{OH})_{8}\left(\left(\mathrm{C}_{6} \mathrm{H}_{5} \mathrm{O}\right)_{2} \mathrm{PO}_{2}\right)_{12}$, was reported by Mokry in 1996, and it was synthesized by reacting uranyl acetate with diphenylphosphate and $\left[\mathrm{TpVCl}_{2}(\mathrm{dmf})\right](\mathrm{Tp}=$ hydridotris(pyrazolyl)borate) in acetonitrile under inert atmosphere. ${ }^{\mathbf{1 4}}$ After that, several $\mathrm{U}(\mathrm{vI})$ clusters containing 6 to 38 uranium atoms were discovered in various organic solvents under inert atmosphere by reducing U(VI), oxidizing U(III) or using U(Iv) directly.

\footnotetext{
${ }^{a}$ Department of Chemistry and Biochemistry, Claflin University, Orangeburg, SC, 29115, USA.E-mail: jling@claflin.edu

${ }^{b}$ State Key Laboratory of Radiation Medicine and Protection, School for Radiological and Interdisciplinary Sciences, Collaborative Innovation Center of Radiation Medicine of Jiangsu Higher Education Institution, Soochow University, Suzhou, 215123, China

$\dagger$ Electronic supplementary information (ESI) available: Experimental methods, crystallographic tables, and additional data figures and analysis. CCDC 1850747-1850749. For ESI and crystallographic data in CIF or other electronic format see DOI: 10.1039/c8ra06330c
} $\mathrm{OTf})_{8}\left(\mathrm{Py}_{8}\right],\left[\mathrm{U}_{6} \mathrm{O}_{8} \mathrm{I}_{8}(\mathrm{Py})_{10}\right],\left[\mathrm{U}_{6} \mathrm{O}_{8}(\mathrm{OTf})_{8}(\mathrm{THF})_{8}\right]$, and $\left[\mathrm{U}_{6} \mathrm{O}_{8}\left(\eta^{8}-\right.\right.$ $\left.\left.\mathrm{C}_{8} \mathrm{H}_{8}\right)(\mathrm{OTf})_{6}(\mathrm{Py})_{8}\right]$, by reacting $\left[\mathrm{U}\left(\eta^{8}-\mathrm{C}_{8} \mathrm{H}_{8}\right)_{2}\right]$ with $\left[\mathrm{UO}_{2}(\mathrm{OTf})_{2}\right]$ or $\left[\mathrm{UO}_{2} \mathrm{I}_{2}(\mathrm{THF})_{3}\right]$ in pyridine or THF solution. ${ }^{15}$ Nocton reported a hexanuclear $\mathrm{U}(\mathrm{vv})$ cluster $\left[\mathrm{U}_{6} \mathrm{O}_{4}(\mathrm{OH})_{4}(\eta-\mathrm{dbm})_{12}\right]$ and a dodecanuclear $\mathrm{U}(\mathrm{iv}) / \mathrm{U}(\mathrm{v})$ cluster $\left[\mathrm{U}_{12}(\mathrm{OH})_{8}(\mathrm{O})_{12} \mathrm{I}_{2}(\mathrm{OTf})_{16}\left(\mathrm{CH}_{3} \mathrm{CN}\right)_{8}\right]$ which were synthesized by reacting $\mathrm{UI}_{3}(\mathrm{OTf})_{4}$ with dbm or triflate in acetonitrile. ${ }^{16}$ Biswas synthesized two large U(Iv) clusters, decanuclear $\left[\mathrm{U}_{10} \mathrm{O}_{8}(\mathrm{OH})_{6}(\mathrm{bz})_{14} \mathrm{I}_{4}\left(\mathrm{H}_{2} \mathrm{O}\right)_{2}\left(\mathrm{CH}_{3} \mathrm{CN}\right)_{2}\right]$ and hexadecanuclear $\left[\mathrm{U}_{16} \mathrm{O}_{22}(\mathrm{OH})_{2}(\mathrm{bz})_{24}\right]$, by reacting $\mathrm{UI}_{3}(\mathrm{THF})_{4}$ with benzoic acid (bz) in acetonitrile solution. ${ }^{17}$ Falaise made the largest $\mathrm{U}(\mathrm{rv})$ cluster, $\left[\mathrm{U}_{38} \mathrm{O}_{56} \mathrm{Cl}_{18}(\mathrm{THF})_{8}(\mathrm{bz})_{24}\right]$, from a solvothermal reaction of $\mathrm{UCl}_{4}$ and benzoic acid in THF solvent. ${ }^{18}$ These $\mathrm{U}(\mathrm{Iv})$ clusters can be also synthesized in aqueous solution with the presence of $\mathrm{N}_{2} \mathrm{H}_{4}$ as a reducing agent. Takao reported the first formate hexanuclear $\mathrm{U}(\mathrm{Ir})$ clusters, $\left[\mathrm{U}_{6} \mathrm{O}_{4}(\mathrm{OH})_{4}(-\right.$ $\left.\mathrm{HCOO})_{12}\left(\mathrm{H}_{2} \mathrm{O}\right)_{6}\right]$ and $\left[\mathrm{U}_{6} \mathrm{O}_{4}(\mathrm{OH})_{4}(\mathrm{HCOO})_{12}\left(\mathrm{H}_{2} \mathrm{O}\right)_{3}\left(\mathrm{CH}_{3} \mathrm{OH}\right)_{3}\right]$, by reacting $\mathrm{U}\left(\mathrm{ClO}_{4}\right)_{4}$ with $\mathrm{HCOOH}$ in acidic aqueous condition. ${ }^{19}$ Tamain discovered three $\mathrm{An}(\mathrm{Iv})(\mathrm{An}=\mathrm{U}, \mathrm{Np}, \mathrm{Pu})$ hexanuclear clusters and the $\mathrm{U}(\mathrm{rv})$ cluster, $\left[\mathrm{U}_{6}(\mathrm{OH})_{4} \mathrm{O}_{4}\left(\mathrm{H}_{2} \mathrm{O}\right)_{8}(\mathrm{HDOTA})_{4}\right]$, was made by reacting $\mathrm{U}\left(\mathrm{NO}_{3}\right)_{4}$ with tetraazacyclododecane- $1,3,7,10$ tetraacetic acid (DOTA) in acidic solution. ${ }^{20}$ Diwu reported four $\operatorname{An}(\mathrm{Iv})(\mathrm{An}=\mathrm{Th}, \mathrm{U}, \mathrm{Np})$ hexanuclear clusters, including two U(rv) clusters, $\left(\mathrm{NH}_{4}\right)_{4} \mathrm{U}_{12} \mathrm{Cs}_{8}\left[\mathrm{C}_{6} \mathrm{H}_{4}\left(\mathrm{PO}_{3}\right)\left(\mathrm{PO}_{3} \mathrm{H}\right)\right]_{12}\left(\mathrm{NO}_{3}\right)_{24} \cdot 18 \mathrm{H}_{2} \mathrm{O}$ and $\left(\mathrm{NH}_{4}\right)_{4} \mathrm{U}_{12} \mathrm{CS}_{2}\left[\mathrm{C}_{6} \mathrm{H}_{4}\left(\mathrm{PO}_{3}\right)\left(\mathrm{PO}_{3} \mathrm{H}\right)\right]_{12}\left(\mathrm{NO}_{3}\right)_{18} \cdot 40 \mathrm{H}_{2} \mathrm{O}$ made by reacting $\mathrm{UCl}_{4}$ and 1,2-phenylenediphosphonic acid at room temperature. ${ }^{21}$ Rather than typical octahedral clusters, those two diphosphonate hexanuclear U(Iv) clusters adopt a planar six-membered ring structure. These discrete U(Iv) clusters have also been extended into infinite two- and three-dimensional structures, for instance, $\left[\mathrm{U}_{6} \mathrm{O}_{4}(\mathrm{OH})_{4}\left(\mathrm{H}_{2} \mathrm{O}\right)_{6}(\mathrm{~L})_{6}\right]\left(\mathrm{L}=4,4^{\prime}\right.$-bpdc, 2,6-ndc, 1,4-bdc, and fum $)_{,}^{22}\left[\mathrm{U}_{6} \mathrm{O}_{8}\left(\mu_{2}-\mathrm{OTf}\right)_{8}\left(\eta_{2}-\mathrm{OTf}\right)_{4}\right]$ and 
$\left[\mathrm{U}_{6} \mathrm{O}_{8}\left(\mu_{2}-\mathrm{OTf}\right)_{12}\left(\mathrm{H}_{2} \mathrm{O}\right)_{3.5}\right]{ }^{23}$ via the linkage of carboxylate and trifluoromethanosulfonate ligands.

In aim to expand the family of U(Iv) polynuclear clusters, we explored the hydrothermal reactions of uranyl acetate with formic acid under alkaline aqueous solution with the presence of reducing agent and discovered three one-dimensional chain structures of hexanuclear U(Iv) core, $\left[\mathrm{U}_{6} \mathrm{O}_{4}(\mathrm{OH})_{4}(\mathrm{HCOO})_{12}\left(\mathrm{H}_{2}\right.\right.$ $\mathrm{O})] \cdot 3 \mathrm{H}_{2} \mathrm{O}(\mathbf{1 a}),\left[\mathrm{U}_{6} \mathrm{O}_{4}(\mathrm{OH})_{4}(\mathrm{HCOO})_{12}(\mathrm{HCOOH})\left(\mathrm{H}_{2} \mathrm{O}\right)\right] \cdot 3 \mathrm{H}_{2} \mathrm{O}(\mathbf{1 b})$ and $\left(\mathrm{H}_{6} \mathrm{C}_{5} \mathrm{~N}\right)_{2}\left[\mathrm{U}_{6} \mathrm{O}_{4}(\mathrm{OH})_{4}(\mathrm{HCOO})_{14}\left(\mathrm{H}_{5} \mathrm{C}_{5} \mathrm{~N}\right)\right]$ (2). To our best knowledge, these are the first one-dimensional structures of U(Iv) clusters. Their syntheses, crystal structures, adsorption spectral and magnetic properties have been investigated and discussed in this work.

\section{Experimental}

\section{Syntheses}

Caution: While the $\mathrm{UO}_{2}(\mathrm{OAc})_{2} \cdot 2 \mathrm{H}_{2} \mathrm{O}$ used in these experiments contains isotopically depleted $\mathrm{U}$, standard precautions for handling radioactive materials should be followed.

$\mathrm{UO}_{2}(\mathrm{OAc})_{2} \cdot 2 \mathrm{H}_{2} \mathrm{O}$ (MV Laboratories, Lot no. P705UA1), $\mathrm{HCOOH}$ (95\%, Alfa-Aesar), $\mathrm{Na}_{2} \mathrm{CO}_{3}$ (99\%, Sigma-Aldrich), and pyridine (99\%, VWR) were used as received. Distilled and Millipore filtered water with a resistance of $18.2 \mathrm{M} \Omega \mathrm{cm}$ was used. $\mathrm{Zn}$ amalgam was prepared in the laboratory by mixing an approximate ratio by weight of $30 \% \mathrm{Zn}: 70 \% \mathrm{Hg}$ in a roundbottom flask. The round-bottom flask was heated on an oil bath pan at $180{ }^{\circ} \mathrm{C}$ until the $\mathrm{Zn}$ completely dissolved into the $\mathrm{Hg}^{24}$ Amalgams were recovered after reactions and reused in subsequent reactions until lost enough $\mathrm{Zn}$ to render them unusable.

In all reactions, $\mathrm{Zn}$ amalgam was added as a reducing agent for the reduction of $\mathrm{U}(\mathrm{vI})$ to $\mathrm{U}(\mathrm{IV})$. Compound $\mathbf{1 a}$ and $\mathbf{1 b}$ were synthesized as co-products from a hydrothermal reaction of $\mathrm{UO}_{2}(\mathrm{OAc})_{2} \cdot 2 \mathrm{H}_{2} \mathrm{O}(0.085 \mathrm{~g}, 0.2 \mathrm{mmol}), \mathrm{Na}_{2} \mathrm{CO}_{3}(0.064 \mathrm{~g}, 0.6$ $\mathrm{mmol}), \mathrm{HCOOH}(1 \mathrm{ml}, 21.7 \mathrm{mmol}), 1 \mathrm{ml} \mathrm{H}_{2} \mathrm{O}$, and $7 \mathrm{~g} \mathrm{Zn}$ amalgam. This reaction was sealed in a $23 \mathrm{ml}$ PTFE-lined autoclave, heated at $150{ }^{\circ} \mathrm{C}$ in a box furnace for 2 hours, and slowly cooled down to room temperature in 12 hours. The products, green rhombohedra crystals, were washed with water and ethanol and left to dry in the air. The yields for compound $\mathbf{1 a}$ and $\mathbf{1 b}$ were not measured due to the difficulty of separating those two phases.

Compound 2 was synthesized under a similar condition as compound 1a and $\mathbf{1 b}$ except $1 \mathrm{ml}$ pyridine was used as solvent instead of $1 \mathrm{ml}$ water. Rod-like green crystals of compound 2 were obtained as single phase product with an approximate yield of $30 \%$ based on $\mathrm{U}$.

\section{Crystallographic studies}

Single crystals of $\mathbf{1 a}, \mathbf{1 b}$ and $\mathbf{2}$ were selected using a polarizedlight stereomicroscope and mounted on tapered glass fibers with epoxy for X-ray diffraction analysis. A sphere of diffraction data was collected for each compound at room temperature using a Bruker APEX DUO diffractometer equipped with an APEX CCD detector. The data were collected using monochromated Mo
Table 1 Selected crystallographic data for compound $1 \mathrm{a}, 1 \mathrm{~b}$ and 2

\begin{tabular}{llll}
\hline Compound & $\mathbf{1 a}$ & $\mathbf{1 b}$ & $\mathbf{2}$ \\
\hline Cryst syst & Monoclinic & Triclinic & Monoclinic \\
Space group & $C 2 / c$ & $P \overline{1}$ & $C 2 / c$ \\
$a(\AA)$ & $20.236(3)$ & $11.5396(5)$ & $20.458(3)$ \\
$b(\AA)$ & $11.821(2)$ & $11.7744(8)$ & $15.473(3)$ \\
$c(\AA)$ & $16.322(2)$ & $16.2574(8)$ & $15.918(2)$ \\
$\alpha($ deg$)$ & & $77.994(3)$ & \\
$\beta($ deg) & $104.698(4)$ & $77.951(2)$ & $107.718(10)$ \\
$\gamma($ deg) & & $60.742(2)$ & \\
$V\left(\AA^{3}\right)$ & $3776.7(9)$ & $1870.1(2)$ & $4799.9(13)$ \\
$Z$ & 4 & 2 & 4 \\
$D_{\text {calcd }}$ & 3.895 & 3.893 & 3.360 \\
$T($ K) & 296 & 296 & 296 \\
$\lambda(\AA)$ & 0.71073 & 0.71073 & 0.71073 \\
$F(000)$ & 3816 & 1868 & 4272 \\
$\theta$-max $($ deg $)$ & 27.52 & 30.157 & 27.44 \\
Mu & 25.760 & 26.008 & 20.283 \\
Reflns & 4221 & 10777 & 5569 \\
Indep. reflns & 3292 & 7370 & 4179 \\
$R_{1}(\%)$ & 3.51 & 4.38 & 2.96 \\
wR $R_{2}(\%)$ & 6.52 & 9.01 & 5.85 \\
$S$ & 1.07 & 0.90 & 0.95 \\
& & &
\end{tabular}

$\mathrm{K} \alpha \mathrm{X}$-ray radiation with a frame width $0.5^{\circ}$ in $\omega$ and an exposure time per frame 20 second. Unit cell parameters were refined by least-squares techniques using the Bruker SMART software. ${ }^{25}$ The SAINT software ${ }^{26}$ was used for data integration including Lorentz, background and polarization corrections. Empirical absorption corrections were applied using the SADABS program. ${ }^{27}$ SHELXTL was used for the solution and refinement of the crystal structures. $^{28}$ Atomic coordinates and additional structural information are provided in the cif files which can be accessed for free at the Cambridge Crystallographic Data Center (CCDC) with deposition numbers 1850747 (compound 1a), 1850748 (compound 1b) and 1850749 (compound 2). Selected data collection parameters and crystallographic information are listed in Table 1.

\section{UV-vis-NIR absorption spectroscopy}

UV-vis-NIR absorption spectra for all three compounds were acquired from single crystals using a Craic Technology microspectrophotometer. Crystals were placed on a glass slide under Krytox oil and the data were collected from $300 \mathrm{~nm}$ to $1700 \mathrm{~nm}$ at ambient condition. The exposure time was auto-optimized by the instrument software, and spectra were background corrected for the slide and oil.

\section{Powder X-ray diffraction}

Powder pattern of ground crystalline samples obtained from the reactions of compound $\mathbf{1 a}$ and $\mathbf{1 b}$, and compound $\mathbf{2}$ were collected from $5^{\circ}$ to $50^{\circ}$, with a step of $0.02^{\circ}$ using a Bruker D8 advance $\mathrm{X}$-ray diffractometer with $\mathrm{Cu}-\mathrm{K} \alpha$ radiation $(\lambda=1.54056$ $\AA$ ) equipped with a Lynxeye one-dimensional detector.

\section{Magnetic property measurement}

Magnetic property of compound 2 was analysed by a Quantum Design MPMS-XL SQUID magnetometer. Pure samples of 
ground crystals of compound 2, checked by PXRD, were weighted on a balance sensitive to $0.01 \mathrm{mg}$ and loaded into a SQUID magnetometer. Its magnetic susceptibility data were measured in an applied field of $0.1 \mathrm{~T}$ in the temperature range of 2 to $300 \mathrm{~K}$. The magnetic properties of compound $\mathbf{1 a}$ and $\mathbf{1 b}$ were not examined due to the failure of getting enough pure phases.

\section{Results and discussion}

\section{Syntheses}

Several attempts were conducted to get pure phases of compound $\mathbf{1 a}$ and $\mathbf{1 b}$ through adjusting mole ratio of reactants, $\mathrm{pH}$ of solution, reaction temperature and time, and amount of water, but no pure phase of either one could be obtained.

\section{Powder X-ray}

Powder X-ray diffraction was used to check the composition of prepared sample. The experimental PXRD pattern of sample obtained from the reaction for compound 2 matches the simulated pattern calculated from the cif file of the structure with program CrystalMaker and it reveals that it is a single phase without any impurity (Fig. S1†).

\section{Crystallographic description}

Single crystal X-ray diffraction reveals that the structures of 1a, $\mathbf{1 b}$, and 2 each contain a typically hexanuclear core as observed in previously reported hexanuclear U(Iv) clusters. ${ }^{\mathbf{1 4 - 2 0 , 2 2}}$ Within the hexanuclear core, six uranium atoms are arranged in a slightly distorted octahedral coordination geometry with $\mathrm{U}-\mathrm{U}$ distances ranging from 3.790-3.875 A and they are bridged by eight $\mu_{3}-\mathrm{O}$ sites which cap eight faces of the octahedron (Fig. 1a). As reported in previous hexanuclear U(Iv) clusters, those eight $\mu_{3}-\mathrm{O}$ sites could be all $\mathrm{O}^{2-}$ groups, or all $\mathrm{OH}^{-}$ groups, or half $\mathrm{O}^{2-}$ and half $\mathrm{OH}^{-}$groups. ${ }^{14-17,19,20,22}$ Although it is difficult to locate the hydrogen atoms of these $\mathrm{O}$ sites and differentiate $\mathrm{OH}^{-}$from $\mathrm{O}^{2-}$ groups directly from electron density map due to the presence of heavy $U$ atoms, those two groups can be distinguished by the $\mathrm{U}-\mathrm{O}$ bond distance. According to literature, $\mathrm{U}(\mathrm{IV})-\mathrm{O}$ distance are restricted to values between 2.21 and $2.27 \AA$, whereas the $\mathrm{U}(\mathrm{IV})-\mathrm{OH}$ distances are substantially longer and have a range from 2.41 to 2.48 $\AA^{16,17,19,20,22}$ In the structure of each compound, there are four $\mathrm{O}$ sites with $\mathrm{U}(\mathrm{Iv})-\mathrm{O}$ bond distances falling into the range of $\mathrm{U}(\mathrm{Iv})-$ $\mathrm{OH}$ bond distance, where other four sites with $\mathrm{U}(\mathrm{Iv})-\mathrm{O}$ bond distances match that of $\mathrm{U}(\mathrm{Iv})-\mathrm{O}$ bond distances. The assignment of $\mathrm{OH}^{-}$and $\mathrm{O}^{2-}$ groups are also confirmed by bond valence calculations carried out for these $\mathrm{O}$ atoms using Brown's parameter (Table $\mathrm{S} 1 \dagger){ }^{29}$ The oxidation state of U(Iv) ions in all three structure are confirmed by bond valence calculations using Burns' parameter. ${ }^{30}$ As a consequence, the hexanuclear core has a composition of $\left[\mathrm{U}_{6} \mathrm{O}_{4}(\mathrm{OH})_{4}\right]^{12+}$.

Compound 1a crystallizes in a monoclinic space group $C 2 / c$ and contains four crystallographically unique uranium(Iv) centers, four $\mu_{3}-\mathrm{O} / \mathrm{OH}$ sites, six formate groups, and four water molecules. Four U(Iv) centers have mixed coordination

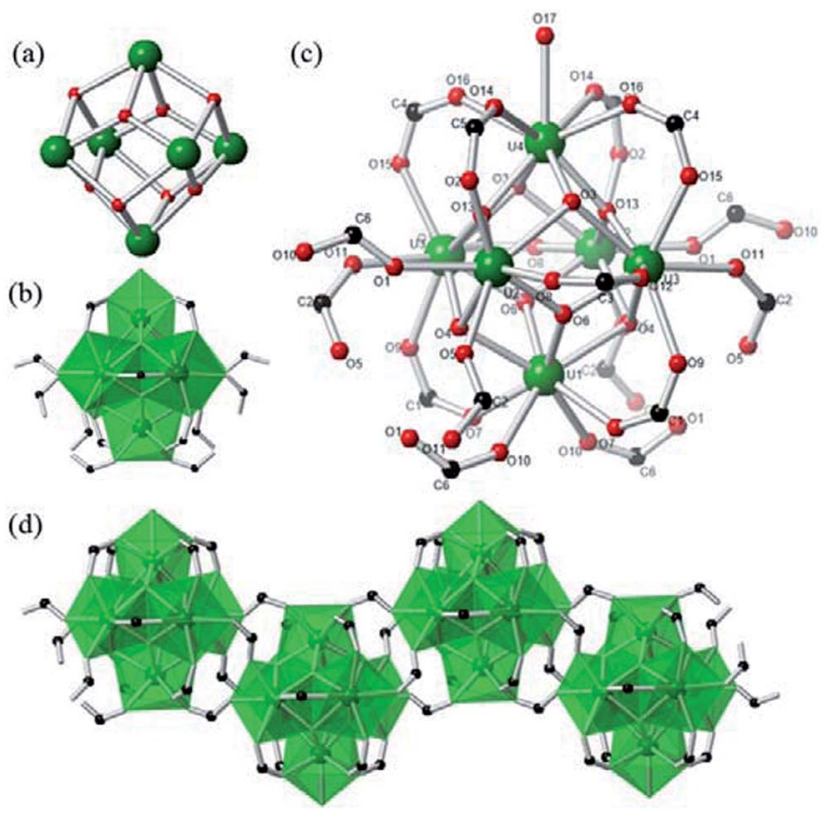

Fig. 1 Crystal structure of compound 1a. (a) Hexanuclear U(IV) core achieved by $\mu_{3}-\mathrm{O}$ and $\mu_{3}-\mathrm{OH}$; (b) polyhedra representation of core decorated by formate ligands; (c) ball-sticks representation of core structure; (d) 1D zig-zag chain of $U($ Iv) clusters (color scheme: $U$, green; $\mathrm{O}$, red; $\mathrm{C}$, black).

environments. Each U1, U2, and U3 atom is eight-coordinated by $\mathrm{O}$ atoms and results a $\mathrm{UO}_{8}$ polyhedron which has a standard $D_{4 \mathrm{~d}}$ square antiprism coordination geometry. Those U atoms are bounded to two $\mu_{3}$-oxo (2.187-2.244 $\AA$ ), two $\mu_{3}$ hydroxo (2.419-2.468 $\mathrm{\AA}$ ) and four carboxylate $\mathrm{O}$ atoms from four $\mathrm{HCOO}^{-}$groups (2.399-2.449 ̊). Each U4 atom adopts a ninecoordinated $\mathrm{UO}_{9}$ capped square antiprism polyhedron in which $\mathrm{U}$ atom is bound to two $\mu_{3}$-oxo $(2.297 \AA)$, two $\mu_{3}$-hydroxo $(2.427 \AA)$, four formate $\mathrm{O}$ atoms $(2.458-2.468 \AA)$ and one terminal coordination water $\mathrm{O}$ atom $(2.460 \AA)$. Six unique $\mathrm{HCOO}^{-}$groups adopt two coordination modes to $\mathrm{U}(\mathrm{Iv})$ centres: $\mathrm{C} 1, \mathrm{C} 3, \mathrm{C} 4$, and C5 formates are bound to two U(Iv) polyhedra within clusters in a syn-syn mode and serve as terminal ligands, while $\mathrm{C} 2$ and $\mathrm{C} 6$ formates adopt a syn-anti mode and they act as bridges to connect two U(Iv) polyhedra from two adjacent hexanuclear clusters. Six U(Iv) polyhedra are joined together by sharing the $\mu_{3}-\mathrm{O} / \mathrm{OH}$ edges of one polyhedral with four neighbouring polyhedral and form a $\left[\mathrm{U}_{6} \mathrm{O}_{4}(\mathrm{OH})_{4}\right]^{12+}$ hexanuclear $\mathrm{U}(\mathrm{Iv})$ core (Fig. 1a). These hexanuclear cores are further decorated by syn-syn formates (C1, C3, C4, C5) groups and linked together by syn-anti formates (C2, C6) (Fig. $1 \mathrm{~b}$ and c), and as a consequence, result an infinitely zig-zag one-dimensional chain structure $\left[\mathrm{U}_{6} \mathrm{O}_{4}(\mathrm{OH})_{4}(\mathrm{HCOO})_{12}\left(\mathrm{H}_{2} \mathrm{O}\right)\right]$ (Fig. 1d). Three free waters are found in the open space between the chains and make an overall composition of $\left[\mathrm{U}_{6} \mathrm{O}_{4}(\mathrm{OH})_{4}(\mathrm{HCOO})_{12}\left(\mathrm{H}_{2} \mathrm{O}\right)\right]$. $3 \mathrm{H}_{2} \mathrm{O}$ for compound $1 \mathrm{a}$.

Compound $\mathbf{1 b}$ crystallizes in a triclinic $P \overline{1}$ space group. In the structure of compound $\mathbf{1 b}$, there are six unique uranium(Iv) centers, eight $\mu_{3}-\mathrm{O} / \mathrm{OH}$ sites, 13 formate groups, and four water molecules. U(IV) centers, U3, U4, U5, and U6, adopt the standard $D_{4 \mathrm{~d}}$ square antiprism coordination geometry and coordinate 


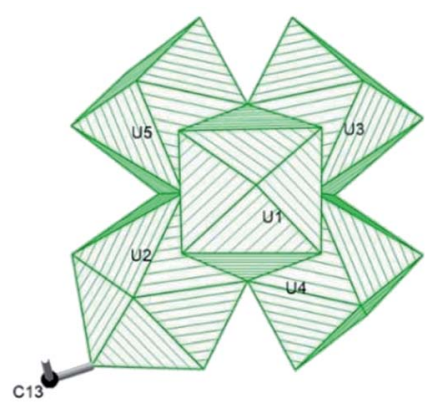

Compound 16

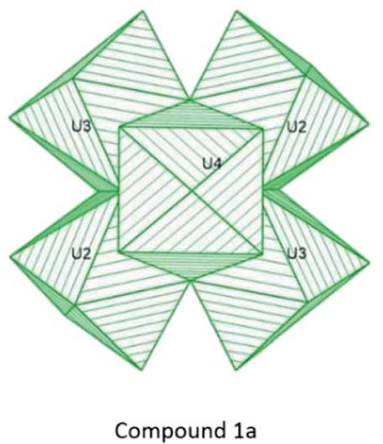

Compound 1a

Fig. 2 Coordination geometry of hexanuclear U(IV) cores in compound $1 \mathrm{~b}$ (left) and $1 \mathrm{a}$ (right).

with eight oxygen atoms belonging to two $\mu_{3}$-oxo (2.187-2.242 $\AA$ )), two $\mu_{3}$-hydroxo (2.408-2.468 $)$ and four carboxylate $\mathrm{O}$ atoms from four $\mathrm{HCOO}^{-}$groups (2.387-2.442 $\left.\mathrm{\AA}\right)$. U1 and U2 are both nine-coordinate and adopt a similar capped square antiprism geometry, but they display different coordination environments. U1 is surround by two $\mu_{3}$-oxo $(2.297 \AA)$, two $\mu_{3}$-hydroxo $(2.427 \AA)$, four formate $O$ atoms $(2.458-2.468 \AA)$ and one terminal coordination water $\mathrm{O}$ atom $(2.460 \AA)$, while U2 doesn't have any coordinated terminal water, instead has a terminal monodentate formate (C13) ligand (Fig. 2). The long bond distances of U2-O35 (2.877(14) ̊) and C-O (1.40(3) ̊̊), as well as the bond valence calculations on the $\mathrm{O} 34$ and $\mathrm{O} 35$ atoms, indicate that $\mathrm{C} 13$ formate ligand is a neutral $\mathrm{HCOOH}$ molecule. Thirteen formate units are found in the structure and they adopt three different coordination modes to U(Iv) centers; C1, C3, C4, C5, C7, C9, C10, C11 formates act as decorating bidentate ligands for hexanuclear core in a syn-syn mode, C2, C6, C8, C12 formates serve as bridging ligands for connecting adjacent hexanuclear cores, and C13 formate, as a formic acid molecule, attaches to $\mathrm{U}(2)$ as a terminal monodentate ligand. There are also three free water molecules found in the open space of chain structure and it results an overall composition of $\left[\mathrm{U}_{6} \mathrm{O}_{4}(\mathrm{OH})_{4}(\mathrm{HCOO})_{12}(\mathrm{HCOOH})\left(\mathrm{H}_{2} \mathrm{O}\right)\right] \cdot 3 \mathrm{H}_{2} \mathrm{O}$.

Compound 2 crystallizes in a monoclinic space group $\mathrm{C} 2 / \mathrm{c}$ and it contains four unique $\mathrm{U}(\mathrm{Iv})$ centers, four $\mu_{3}-\mathrm{O} / \mathrm{OH}$ sites, seven formate groups, and two pyridine groups. Among four $\mathrm{U}$ centers, three centers, U1, U2, and U3, adopt an eightcoordination square antiprism, while the other, $\mathrm{U}(4)$, has a nine-coordination capped square antiprism geometry. Within the $\mathrm{UO}_{8}$ polyhedra, $\mathrm{U}(\mathrm{Iv})$ ion is coordinated by two $\mu_{3}$ oxo (2.219-2.255 $\AA$ ), two $\mu_{3}$-hydroxo $(2.390-2.464 \AA)$ and four carboxylate $\mathrm{O}$ atoms from four $\mathrm{HCOO}^{-}$groups (2.319-2.466 $\left.\mathrm{A}\right)$. For the nine-coordinated $\mathrm{U} 4$, the $\mathrm{H}_{2} \mathrm{O}$ site of $\mathrm{UO}_{9}$ polyhedron in compound 1a is occupied by one $\mathrm{N}$ atom of pyridine molecule with a U-N bond distance 2.769(8) A. The remaining vertices of this capped square antiprism are occupied by two $\mu_{3}$-oxo $(2.288 \AA)$, two $\mu_{3}$-hydroxo $(2.497 \AA)$ and four carboxylate $\mathrm{O}$ atoms from four $\mathrm{HCOO}^{-}$groups $(2.415-2.425 \AA)$. Seven formate units adopt three coordination modes to $\mathrm{U}(\mathrm{Iv})$ centers. C3, C5, C8 formates act as decorating ligands for hexanuclear core in a syn-syn mode, $\mathrm{C} 2$ and $\mathrm{C} 4$ formates serve as bridging ligands for connecting adjacent hexanuclear cores, while C1

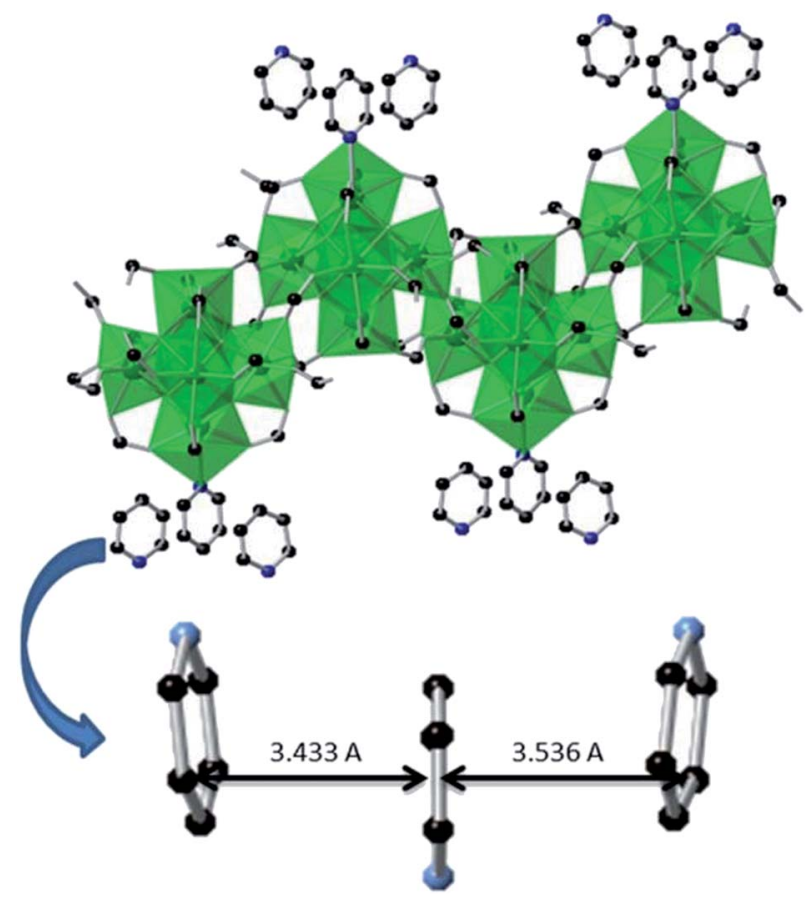

Fig. 3 1D chain of U(IV) clusters and packing mode of pyridine ligands in compound 2 ( $U$, green; $O$, red; $C$, black; $N$, blue).

and $\mathrm{C6}$ formates attach to U(Iv) centers as terminal ligands in a monodentate coordination mode. There are two protonated pyridine groups found in the open space of chain structure and they are stacked together with the coordinated pyridine molecule in an antiparallel-displaced geometry owing to the $\pi-\pi$ interaction $^{31-33}$ with interplanar separation distances 3.433 to $3.536 \AA$ (Fig. 3). This arrangement can be explained by the minimization of electric repulsion between two protonated $\mathrm{N}$ atoms in free pyridine ligands and the partially positively charged $\mathrm{N}$ atom in the coordinated pyridine ligand. Overall, compound 2 has a composition of $\left(\mathrm{H}_{6} \mathrm{C}_{5} \mathrm{~N}\right)_{2}\left[\mathrm{U}_{6} \mathrm{O}_{4}(\mathrm{OH})_{4}(\mathrm{HCOO})_{14}\left(\mathrm{H}_{5} \mathrm{C}_{5} \mathrm{~N}\right)\right]$.

\section{Structure comparison}

Although three compounds adopt similar zig-zag onedimensional chain structures of hexanucler U(Iv) clusters, the $\mathrm{U}$ centers and formate groups display some distinct coordination environments.

By comparing the formulas of $1 \mathrm{a},\left[\mathrm{U}_{6} \mathrm{O}_{4}(\mathrm{OH})_{4}(\mathrm{HCOO})_{12}\left(\mathrm{H}_{2}-\right.\right.$ $\mathrm{O})] \cdot 3 \mathrm{H}_{2} \mathrm{O}$, and $\mathbf{1 b},\left[\mathrm{U}_{6} \mathrm{O}_{4}(\mathrm{OH})_{4}(\mathrm{HCOO})_{12}(\mathrm{HCOOH})\left(\mathrm{H}_{2} \mathrm{O}\right)\right] \cdot 3 \mathrm{H}_{2} \mathrm{O}$, it is notable that compound $\mathbf{1 b}$ contains one extra $\mathrm{HCOOH}$ ligand. As depicted in Fig. 2, the extra $\mathrm{HCOOH}$ molecule in compound $\mathbf{1 b}$, marked as $\mathrm{C} 13$ formate group, attaches to U2 and results a $\mathrm{UO}_{9}$ polyhedra rather than a $\mathrm{UO}_{8}$ polyhedra in compound 1a. Although the introduction of an extra formic acid molecule doesn't change the dimension of the chain structure too much, it decreases the symmetry of chain structure from a monoclinic $C 2 / c$ space group in compound 1 a to a triclinic $P \overline{1}$ space group in compound $\mathbf{1 b}$.

It was described in the experimental section that compound 2 was made under similar synthetic conditions as compounds 
1a and 1b except using pyridine as a solvent instead of water. As a consequence, the water groups within compound $\mathbf{1 a}$ and $\mathbf{1 b}$ should be replaced by pyridine groups. As expected, single crystal XRD reveals that the water molecule sites within the hexanuclear cores in compound $\mathbf{1 a}$ and $\mathbf{1 b}$ are substituted by pyridine groups (Fig. 3). The free water molecules in compound $\mathbf{1 a}$ and $\mathbf{1 b}$ are also replaced by pyridine groups. The introduction of pyridine group increases the dimension of clusters. As seen in Table 1 , compounds $\mathbf{1 a}$ and $\mathbf{2}$ crystallize in the same monoclinic $C 2 / c$ space group, but compound 2 has a larger value of $b$ (compound 1a: $b=11.812$; compound 2: $b=15.473$ ) and it is due to the alignment of pyridine groups along the $y$ axis.

In all three chain structures, hexanuclear U(IV) clusters contain both eight- and nine-coordinated U(IV) polyhedra and those polyhedra are connected by edge-sharing $\mu_{3}-\mathrm{O} / \mathrm{OH}$ groups. $\mathrm{UO}_{8}$ polyhedra from adjacent clusters are further linked together through syn-anti formate groups and result a chain structure aligning along the $z$ direction. While for the nine-coordinated $\mathrm{UO}_{9}$ or $\mathrm{UO}_{8} \mathrm{~N}$ polyhedron, the coordinated water (compound $\mathbf{1 a}$ and $\mathbf{1 b}$ ) or pyridine (compound 2) molecule, acting as a terminal ligand, prevents the extension of clusters on the $x y$ plane. This mixed coordination numbers of U(IV) within the same cluster are not observed in any previously reported U(Iv) polynuclear clusters. ${ }^{14-23}$ For the clusters containing large organic ligands, such as diphenylphosphate, ${ }^{14}$ benzoate,${ }^{17,18}$ DOTA,${ }^{20}$ OTf, ${ }^{15,23}$ and dbm,${ }^{16}$ the $\mathrm{U}(\mathrm{Iv})$ ions usually adopt a $\mathrm{UO}_{8}$ polyhedra; While for small ligands, such as formate, $\mathrm{U}(\mathrm{Iv})$ can have a $\mathrm{UO}_{9}$ polyhedra as found in the structure of $\left[\mathrm{U}_{6} \mathrm{O}_{4}(\mathrm{OH})_{4}(\mathrm{HCOO})_{12}\left(\mathrm{~L}_{\mathrm{t}}\right)_{6}\right]\left(\mathrm{L}_{\mathrm{t}}=\mathrm{H}_{2} \mathrm{O}\right.$ or $\left.\mathrm{CH}_{3} \mathrm{OH}\right) .{ }^{22} \mathrm{UO}_{9}$ polyhedra is also seen in the phenylenediphosphonate incorporated hexanuclear $\mathrm{U}(\mathrm{IV})$ clusters, $\left(\mathrm{NH}_{4}\right)_{4} \mathrm{U}_{12} \mathrm{Cs}_{8}\left[\mathrm{C}_{6} \mathrm{H}_{4}\left(\mathrm{PO}_{3}\right)\left(\mathrm{PO}_{3} \mathrm{H}\right)\right]_{12}\left(\mathrm{NO}_{3}\right)_{24} \cdot 18 \mathrm{H}_{2} \mathrm{O}$ and $\left(\mathrm{NH}_{4}\right)_{4} \mathrm{U}_{12} \mathrm{Cs}_{2}\left[\mathrm{C}_{6} \mathrm{H}_{4}\left(\mathrm{PO}_{3}\right)\left(\mathrm{PO}_{3} \mathrm{H}\right)\right]_{12}\left(\mathrm{NO}_{3}\right)_{18} \cdot 40 \mathrm{H}_{2} \mathrm{O}$, which may be due to the lesser compact arrangement of $\mathrm{U}(\mathrm{Iv})$ polyhedral as a planar six-membered ring. ${ }^{21}$ The coordination mode of ligands also plays a vital role on the structure of U(Iv) clusters. All ligands in the previous reported U(Iv) clusters adopt a synsyn coordination mode to uranium metals and they serve as decorating ligands for the polynuclear core. ${ }^{\mathbf{1 4 - 2 3}}$ While in the structures of three compounds reported here, formate ligands can have both syn-syn and syn-anti coordination modes and the later coordination mode enable the linkage of clusters and results the formation of extended chain structures of clusters.

\section{UV-vis-NIR absorption}

$\mathrm{U}(\mathrm{Iv})$, which has a $[\mathrm{Rn}] 5 \mathrm{f}^{2}$ electron configuration, is known to produce a series of weak Laporte-forbidden $\mathrm{f}-\mathrm{f}$ transitions in UV-vis-NIR region. In most cases, these transitions show relatively small variations with changing coordination environment, and they can be used as fingerprints to identify the oxidation states of uranium. ${ }^{34,35}$

UV-vis-NIR absorption spectra of compound $\mathbf{1 a}, \mathbf{1 b}$ and $\mathbf{2}$ are arranged from top to bottom in Fig. 4. For all three compounds, the strongest absorption bands are observed in the range of 580

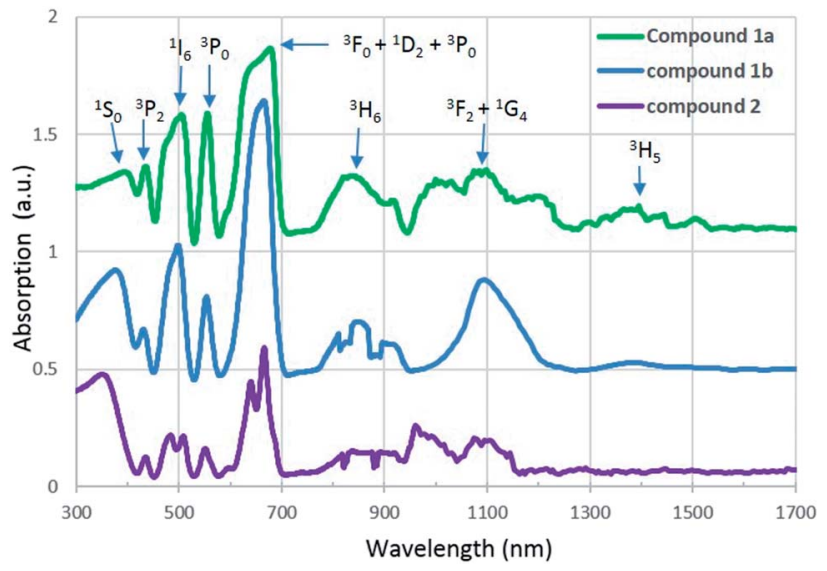

Fig. 4 UV-vis-NIR absorption spectra of compound $1 \mathrm{a}, 1 \mathrm{~b}$ and 2.

to $709 \mathrm{~nm}$ and they can be assigned to transitions of the ${ }^{3} \mathrm{H}_{4}$ ground state of $\mathrm{U}^{4+}$ to the mixture energy levels of ${ }^{3} \mathrm{~F}_{4},{ }^{1} \mathrm{D}_{2}$ and ${ }^{3} \mathrm{P}_{0}$. The band in the lowest spectral region of 300 to $400 \mathrm{~nm}$ is attributed to transition from the ${ }^{3} \mathrm{H}_{4}$ ground state to the ${ }^{1} \mathrm{~S}_{0}$ excited state. Three absorption bands located around 435, 504 and $556 \mathrm{~nm}$ correspond to the multiplets of ${ }^{3} \mathrm{P}_{2},{ }^{1} \mathrm{I}_{6}$ and ${ }^{3} \mathrm{P}_{1}$. In addition, two sets of absorption bands occuring in the regions 760-940 $\mathrm{nm}$ and 940-1260 $\mathrm{nm}$ are due to the transition of $\mathrm{U}^{4+}$ from ground state to the multiplet of ${ }^{3} \mathrm{H}_{6}$ and a mixture of several levels of ${ }^{3} \mathrm{~F}_{3}$ and ${ }^{1} \mathrm{G}_{4}$. In contrast to compound 2 , an extra peak at $1400 \mathrm{~nm}$ is found in the spectra of compound $\mathbf{1 a}$ and $\mathbf{1 b}$ and it corresponds to the multiplet of ${ }^{3} \mathrm{H}_{5}$. All of these absorption values are in agreement with those of $\mathrm{U}^{4+}$ in the literature..$^{21,36}$

\section{Magnetic properties}

Different from $\mathrm{U}(\mathrm{vI})\left(5 \mathrm{f}^{0}\right), \mathrm{U}(\mathrm{Iv})$, a $5 \mathrm{f}^{2}$ system, typically exhibits a paramagnetic property arised from a combination of spinorbital interactions and crystal field effects. ${ }^{37,38}$ Magnetic properties of many typical U(Iv) compounds, including mono- or binuclear and regular extended structures, have been well characterized, ${ }^{38}$ while that of polynuclear complexes are rarely investigated. ${ }^{\mathbf{1 6 - 1 8 , 2 3}}$ In addition, the magnetic property, such as magnetic susceptibility data, can be used to identify the oxidation states of $\mathrm{U}$ in those compounds.

The magnetic susceptibility data for compound 2 was collected over the temperature range of $2-300 \mathrm{~K}$ in an applied filed of $0.1 \mathrm{~T}$. No differences were observed between the zerofield cooled (ZFC) and field cooled (FC) data. As shown in Fig. 5 (green curve), compound 2 shows paramagnetic characteristics and $\chi$ increases with decreasing the temperature.

In the high temperature region above $150 \mathrm{~K}$ (Fig. S2 and S3†), the magnetic susceptibility curve follows the Curie-Weiss $(\mathrm{C}-\mathrm{W})$ law. The inverse susceptibility data above $150 \mathrm{~K}$ was fitted to the $\mathrm{C}-\mathrm{W}$ law $(\chi=C /(T-$ theta $))$, resulting in values of $8.790 \mathrm{emu} \mathrm{K}$ $\mathrm{mol}^{-1}$ and $-248.07 \mathrm{~K}$ for the Curie and Weiss constants, respectively. From the Curie constant, an effective magnetic moment of $\mu_{\text {eff }}=3.42 \mu_{\mathrm{b}}$ per $\mathrm{U}^{4+}$ ion at $300 \mathrm{~K}$ is obtained and it is slightly lower than $3.58 \mu_{\mathrm{b}}$ calculated from Russell-Saunders 


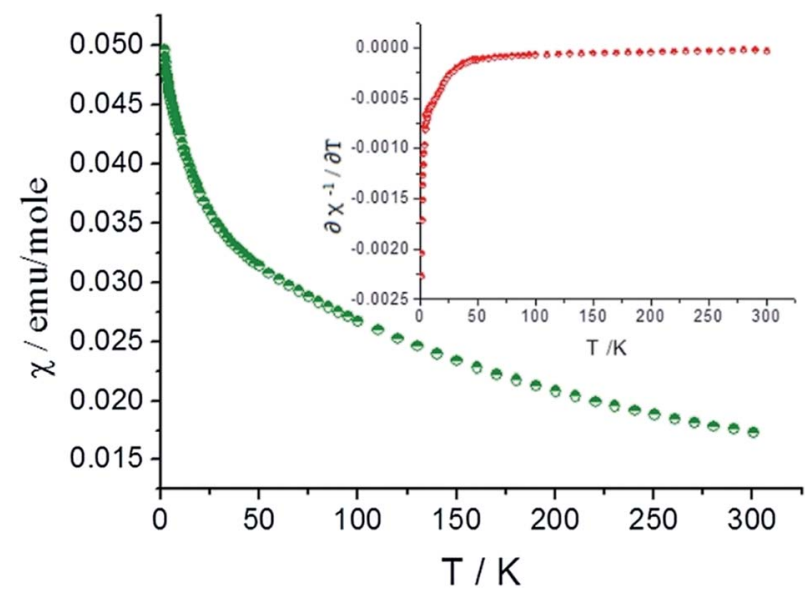

Fig. 5 Magnetic susceptibility curve of compound 2 .

coupling of a ${ }^{3} \mathrm{H}_{4}$ ground state. This is normally for $\mathrm{U}(\mathrm{Iv})$ oxides $^{39,40}$ and the value falls into the range of previously reported effective magnetic moment for other mononuclear and polynuclear U(Iv) complexes $\left(2.5-3.55 \mu_{\mathrm{b}}\right)^{41,42}$.

Below $150 \mathrm{~K}$, the magnetic susceptibility curve deviates from Curie-Weiss law and it is mainly due to the formation of $\mathrm{f}^{2}$ electronic singlet of $\mathrm{U}(\mathrm{Iv})$ at low temperature and the population eliminating process of thermally excited state. As shown in Fig. $\mathrm{S} 4, \uparrow$ the $\chi T$ value approaches zero at low temperature and it is characteristic feature for $\mathrm{U}^{4+}$ ions. ${ }^{38}$ The differential results of the function relation between reversed magnetic susceptibility $\left(\chi^{-1}\right)$ and temperature (inserted graph, red curve) indicate the transition from the $\mathrm{f}^{2}$ electronic triplet to singlet of $\mathrm{U}(\mathrm{rv})$ take place at $25 \mathrm{~K}$.

\section{Conclusions}

Three one-dimensional chain structures of uranium(Iv) hexanuclear clusters have been synthesized under hydrothermal or solvothermal conditions by reacting $\mathrm{U}(\mathrm{vI})$ with formic acid in the presence of $\mathrm{Zn}$ amalgam. Single crystal XRD reveals that the six eight- or nine-coordinated U(Iv) centers are joined together through $\mu_{3}-\mathrm{O}$ and $\mu_{3}-\mathrm{OH}$ groups and result a hexanuclear core. Those U(Iv) hexanuclear cores are decorated by terminal formate ligands and further linked into onedimensional chain structures by bridging formate ligands. UV-vis-NIR spectra of compounds $\mathbf{1 a}, \mathbf{1} \mathbf{b}$ and $\mathbf{2}$ show characteristic U(Iv) peaks. The magnetic susceptibility data of compound 2 indicate that it exhibits paramagnetic characteristics.

\section{Conflicts of interest}

There are no conflicts to declare.

\section{Acknowledgements}

This work was supported by the Department of Energy Minority Serving Institution Partnership Program (MSIPP) managed by the Savannah River National Laboratory under SRNS contract DE-AC09-08SR22470.

\section{Notes and references}

1 L. R. Morss, N. M. Edelstein and J. Fuger, The Chemistry of the Actinide and Transactinide Elements, Springer, Dordrecht, 2006.

2 M. P. Neu, G. S. Goff and W. Runde, in Radionuclides in the Environment, ed. D. A. Atwood, Wiley, Chichester, 2010.

3 J. Qiu and P. C. Burns, Chem. Rev., 2013, 111, 1097-1120.

4 V. Mougel, P. Horeglad, G. Nocton, J. Pecaut and M. Mazzanti, Angew. Chem., Int. Ed., 2009, 48, 8477-8480.

5 M. J. Sarsfield, R. J. Taylor and C. J. Maher, Radiochim. Acta, 2007, 95, 677-682.

6 P. B. Duval, C. J. Burns, D. L. Clark, D. E. Morris, B. L. Scott, J. D. Thompson, E. L. Werkema, L. Jia and R. A. Andersen, Angew. Chem., Int. Ed., 2001, 40, 3357-3361.

7 V. Neck and J. I. Kim, Radiochim. Acta, 2001, 89, 1-16.

8 T. Fanghanel and V. Neck, Pure Appl. Chem., 2002, 74, 18951907.

9 A. B. Kersting, D. W. Efurd, D. L. Finnegan, D. J. Rokop, D. K. Smith and J. L. Thompson, Nature, 1999, 397, 56-59.

10 A. P. Novikov, S. N. Kalmykov, S. Utsunomiya, R. C. Ewing, F. Horreard, A. Merkulov, S. B. Clark, V. Tkachev and B. F. Myasoedov, Science, 2006, 314, 638-641.

11 G. R. Choppin, J. Radioanal. Nucl. Chem., 2007, 273, 695-703. 12 Y. Suzuki, S. D. Kelly, K. M. Kemner and J. F. Banfield, Nature, 2002, 419, 134.

13 M. P. Neu, G. A. Icopini and H. Boukhalfa, Radiochim. Acta, 2005, 98, 705-714.

14 L. M. Mokry, N. S. Dean and C. J. Carrano, Angew. Chem., Int. Ed., 1996, 35, 1497-1498.

15 J. C. Berthet, P. Thuery and M. Ephritikhine, Chem. Commun., 2005, 3415-3417.

16 G. Nocton, J. Pecaut, Y. Filinchuk and M. Mazzanti, Chem. Commun., 2010, 46, 2757-2759.

17 B. Biswas, V. Mougel, J. Pécaut and M. Mazzanti, Angew. Chem., Int. Ed., 2011, 50, 5744-5747.

18 C. Falaise, C. Volkringer, J. Vigier, A. Beaurain, P. Roussel, P. Rabu and T. Loiseau, J. Am. Chem. Soc., 2013, 135, 15678-15681.

19 S. Takao, K. Takao, W. Kraus, F. Emmerling, A. C. Scheinost, G. Bernhard and C. Hennig, Eur. J. Inorg. Chem., 2009, 47714775.

20 C. Tamain, T. Dumas, C. Hennig and P. Guilbaud, Chem.Eur. J., 2017, 23, 6864-6875.

21 J. Diwu, S. Wang and T. E. Albrecht-Schmitt, Inorg. Chem., 2012, 51, 4088-4093.

22 C. Falaise, C. Volkringer, J. Vigier, N. Henry, A. Beaurain and T. Loiseau, Chem.-Eur. J., 2013, 19, 5324-5531.

23 G. Nocton, F. Burdet, J. Pecaut and M. Mazzanti, Angew. Chem., Int. Ed., 2007, 119, 7718-7722.

24 J. N. Cross, E. M. Villa, V. R. Darling, M. J. Polinski, J. Lin, X. T. N. Kikugawa, M. Shatruk, R. Baumbach and T. E. Albrecht-Schmitt, Inorg. Chem., 2014, 53, 7455-7466. 25 Bruker AXS, SAINT, Bruker AXS, Madison, WI, 1998. 
26 Bruker AXS, SMART, Bruker AXS, Madison, WI, 1998. 27 Bruker AXS, SADABS, Bruker AXS, Madison, WI, 1998.

28 G. M. Sheldrick, Acta Crystallogr., Sect. A: Found. Crystallogr., 2008, 64, 112-122.

29 I. D. Brown and D. Altermatt, Acta Crystallogr., Sect. B: Struct. Sci., 1985, 41, 244-247.

30 P. C. Burns, R. C. Ewing and F. C. Hawthorne, Can. Mineral., 1997, 35, 1551-1570.

31 B. K. Mishra and N. Sathyamurthy, J. Phys. Chem. A, 2005, 109, 6-8.

32 N. J. Singh, S. K. Min, D. Y. Kim and K. S. Kim, J. Chem. Theory Comput., 2009, 5, 515-529.

33 A. Das, A. D. Jana, S. K. Seth, B. Dey, S. R. Choudhury, T. Kar, S. Mukhopadhyay, N. J. Singh, I. Hwang and K. S. Kim, J. Phys. Chem. B, 2010, 114, 4166-4170.

34 W. T. Carnall, G. K. Liu, C. W. Williams and M. F. Reid, J. Chem. Phys., 1991, 95, 7194-7203.
35 K. Binnemans, I. Couwenberg, H. De Leebeeck, C. GorllerWalrand and J. L. Adama, J. Alloys Compd., 1999, 285, 105111.

36 A. T. Chemey, J. M. Sperling and T. E. Albrecht-Schmitt, $R S C$ Adv., 2018, 8, 28642-28648.

37 B. R. Judd, Phys. Rev., 1962, 125, 613-625.

38 D. R. Kindra and W. J. Evans, Chem. Rev., 2014, 114, 88658882.

39 J. B. Felder, S. Calder and H. zur Loye, Inorg. Chem., 2018, 57, 9286-9295.

40 G. Morrison, H. Ramanantoanina, W. Urland, M. D. Smith and H. zur Loye, Inorg. Chem., 2015, 54, 5504-5511.

41 E. A. Boudreaux and L. N. Mulay, Theory and Applications of Molecular Paramagnetism, Wiley, New York, 1976.

42 I. Castro-Rodriguez and K. Meyer, Chem. Commun., 2006, 1353-1368. 